\title{
TEORI PERAN DAN KONSEP EXPECTATION-GAP FUNGSI PENGAWASAN DALAM PENGELOLAAN KEUANGAN DESA
}

\author{
Made Aristia Prayudi \\ prayudi.acc@undiksha.ac.id \\ Gusti Ayu Ketut Rencana Sari Dewi \\ Diota Prameswari Vijaya \\ Luh Putu Ekawati \\ Universitas Pendidikan Ganesha
}

\begin{abstract}
The purpose of this study is to empirically investigate the existence of a supervisory function expectation-gap on Indonesian village financial management. It is also aimed at examining the relationship between the extent of supervisory function expected by the Village Consultative Body (Badan Permusyawaratan Desa-BPD) and its performance. The data was collected through a self-administered questionnaire distributed to the members of $B P D$, village communities, Camat and the members of the regional inspectorate of Buleleng Regency of Bali Province. The results of the Mann-Whitney test revealed that there exists a BPD's supervisory function expectation-gap between the members of BPD and (a) village communities regarding the existed duties and the unreasonably expected duties of BPD; (b) Camat regarding the non-existed duties of BPD; (c) regional inspectorate regarding the existed duties, the non-existed duties and the unreasonably expected duties of BPD. Furthermore, the results of the Ordinal Regression analysis indicate a significant positive relationship between the expectation degree of supervisory function perceived by members of BPD and their performance. The findings have implications for understanding the expectation-gap phenomenon on Indonesian village financial management supervisory and also on the design of capacity building programs initiatives for members of village governance supervisory institutions in Indonesia.
\end{abstract}

Key words: role theory, expectation-gap, supervisory of village financial management, village consultative body

\begin{abstract}
ABSTRAK
Tujuan dari penelitian ini adalah untuk secara empiris menyelidiki munculnya kesenjangan harapan (expectation-gap) fungsi pengawasan pada pengelolaan keuangan desa. Selain itu, penelitian ini juga bertujuan untuk menguji hubungan antara tingkat ekspektasi fungsi pengawasan yang dipersepsikan oleh Badan Permusyawaratan Desa (BPD) dan kinerjanya dalam mengawasi pemerintahan desa. Data dikumpulkan melalui kuesioner yang dibagikan kepada anggota BPD, masyarakat desa, Camat dan anggota inspektorat daerah Kabupaten Buleleng Provinsi Bali. Hasil uji Mann-Whitney mengungkap bahwa terdapat kesenjangan harapan antara fungsi-fungsi BPD antara anggota BPD dan (a) masyarakat desa terkait peran BPD sesungguhnya dan peran pengawasan yang melebihi kapasitas BPD; (b) Camat berkenaan dengan peran pengawasan non BPD; (c) inspektorat kabupaten mengenai peran BPD sesungguhnya, peran pengawasan non BPD dan peran pengawasan yang melebihi kapasitas BPD. Selanjutnya, hasil analisis Regresi Ordinal menunjukkan hubungan yang positif dan signifikan antara tingkat harapan fungsi pengawasan yang dirasakan dan kinerja anggota BPD. Temuan ini berimplikasi pada pemahaman mengenai fenomena kesenjangan-harapan peran pengawasan pengelolaan keuangan desa di Indonesia dan juga pada rancangan program pengembangan kapasitas bagi anggota BPD di Indonesia.
\end{abstract}


Kata kunci: teori peran; kesenjangan-harapan; fungsi pengawasan pengelolaan keuangan desa, badan permusyawaratan desa

\section{PENDAHULUAN}

Aspek pengawasan dalam pengelolaan keuangan desa merupakan hal yang sangat penting dalam memastikan terlaksananya pemerintahan desa yang baik dan bersih (Aini et al., 2018) dan menjamin terwujudnya aspek efisiensi dan efektivitas pengelolaan pemerintah desa (Republik Indonesia, 2008). Peran dan fungsi pengawasan juga sangat bermanfaat dalam rangka mengidentifikasi dan mengantisipasi risikorisiko yang dapat menghambat pencapaian tujuan pengelolaan keuangan desa, misalnya risiko kegagalan penyelenggaraan siklus pengelolaan keuangan desa yang sehat, risiko kegagalan atau keterlambatan penyusunan Laporan Penyelenggaraan Pemerintah Desa termasuk Laporan Pertanggungjawaban Realisasi Pelaksanaan APBDes, serta risiko terjadinya fraud (kecurangan) pengelolaan keuangan (BPKP, 2015). Sayangnya, masih dapat ditemukan adanya indikasi ambiguitas dan tumpang tindih penetapan peran dan pelaksana fungsi pengawasan pengelolaan keuangan pemerintah desa secara yuridis dalam konteks praktis di Indonesia.

Pasal 3 Peraturan Menteri Dalam Negeri Nomor 7 Tahun 2008 tentang Pedoman Tata Cara Pengawasan atas Penyelenggaraan Pemerintahan Desa (Permendagri 7/ 2008) contohnya, menyebutkan bahwa fungsi pengawasan terhadap kebijakan desa, kelembagaan desa, keuangan desa dan kekayaan desa dilaksanakan oleh Pejabat Pengawas Pemerintah pada Inspektorat Kabupaten/Kota. Demikian pula, BPKP (2015) menyatakan bahwa Aparat Pengawasan Intern Pemerintah (APIP), dalam hal ini khususnya inspektorat kabupaten atau kota, memiliki peran penting dalam pengawalan akuntabilitas pengelolaan keuangan desa baik dari sisi assurance maupun consulting. Di sisi lain, pasal 82 Undang-Undang Nomor 6 Tahun 2014 tentang Desa (UU 6/2014) menyebutkan bahwa masyarakat desa memiliki hak untuk terlibat aktif dalam hal pengawasan pelaksanaan pembangunan dan pengelolaan keuangan desa melalui kegiatan pemantauan dan publikasi tentang praktik-praktik pengelolaan keuangan desa. Upaya pengawasan dan pemantauan oleh masyarakat desa ini ditujukkan dalam rangka mendorong terwujudnya aspek akuntabilitas dalam pengelolaan pemerintah desa.

Pada peraturan berbeda yaitu pasal 154 Peraturan Pemerintah Republik Indonesia Nomor 43 Tahun 2014 tentang Peraturan Pelaksanaan Undang-Undang Nomor 6 Tahun 2014 tentang Desa (PP 43/2014), disebutkan bahwa camat juga memiliki tugas pembinaan dan pengawasan desa, di antaranya melalui fasilitasi penyusunan peraturan Desa dan peraturan kepala Desa, fasilitasi administrasi tata Pemerintahan Desa, fasilitasi penerapan dan penegakan peraturan perundang-undangan serta fasilitasi pengelolaan keuangan Desa dan pendayagunaan aset Desa. Camat juga berwenang untuk melakukan penilaian terhadap Laporan Penyelenggaraan Pemerintahan Desa (LPPD) ataupun Rancangan Peraturan Desa (Raperdes) ketika mendapat delegasi kewenangan pembinaan dan pengawasan dari pemerintah kabupaten atau kota. Sementara itu, merujuk pada Peraturan Menteri Dalam Negeri Republik Indonesia Nomor 110 Tahun 2016 tentang Badan Permusyawaratan Desa (Permendagri 110/2016), Badan Permusyawaratan Desa (BPD) dinyatakan merupakan suatu lembaga yang melaksanakan fungsi pemerintahan dalam bentuk pengawasan kinerja kepala desa melalui proses monitoring dan evaluasi terhadap pelaksanaan tugas kepala desa. Dalam konteks pemerintahan desa, BPD sebagai lembaga pengawasan memilki kewajiban untuk melakukan pengendalian terhadap implementasi peraturan desa serta jalannya pemerintahan desa. 
Tujuan utama penelitian ini adalah untuk menginvestigasi munculnya fenomena expectation-gap (kesenjangan-harapan) pada pihak-pihak yang terkait dengan peran dan fungsi pengawasan pengelolaan keuangan pemerintah desa. Secara umum, expectation-gap dapat diartikan sebagai (1) perbedaan antara apa yang masyarakat ekspektasikan atau harapkan akan dicapai oleh subjek tertentu dengan apa yang subjek tersebut ekspektasikan atau harapkan dapat mereka selesaikan secara wajar; atau (2) perbedaan antara tanggung jawabtanggung jawab yang masyarakat ekspektasikan atau harapkan dimiliki oleh subjek tertentu dengan kinerja aktual yang subjek tersebut ekspektasikan atau harapkan dapat mereka wujudkan dan penuhi (Best et al., 2001). Fenomena expectation-gap dapat muncul dalam konteks pengelolaan keuangan desa di Indonesia akibat adanya overlapping peran dan fungsi pengawasan sehingga pihak-pihak yang dilekati peran dan fungsi pengawasan akan merasakan adanya ambiguitas peran atas pelaksanaan pekerjaannya tersebut. Ambiguitas peran berarti suatu kondisi dengan mana seseorang tidak mempunyai keyakinan dan kecukupan informasi mengenai tanggung jawabtanggung jawab yang senyatanya dimiliki, mengenai cara-cara untuk menyelesaikan tanggung jawabnya serta mengenai kejelasan ekspektasi atas peran yang dilekatkan kepadanya (Srikanth dan Jomon, 2013).

Penelitian ini juga bertujuan untuk menguji hubungan antara ekspektasi peran pengawasan dan kualitas kinerja pengawasan pengelolaan keuangan desa. Pengujian dilakukan pada organisasi Badan Permusyawaratan Desa (BPD) sebagai sebuah lembaga yang telah lama ada dan diyakini memiliki peran penting dalam hal pengawasan pemerintahan desa (Republik Indonesia, 2016). BPD juga dipilih dengan mempertimbangkan beberapa hasil penelitian terdahulu yang telah memberi gambaran masih kurang optimalnya pelaksanaan peran-peran yang dimanatkan kepada lembaga pengawasan ini (Dewi et al., 2017; Indrayana et al., 2016; Mangoto, 2016). Hasil penelitian Satriadi (2013), misalnya, yang menunjukkan bahwa BPD di Kecamatan Prayat Barat belum dapat melaksanakan fungsinya secara efektif dalam pelaksanaan pengawasan pemerintahan desa dan masih sebatas pada peran pembentukan panitia pemilihan kepala desa. Penelitian lain yang dilakukan oleh Deri (2017) pada Desa Senambah Kabupaten Kutai Timur juga menemukan bahwa BPD di Desa Senambah masih belum bisa berperan secara optimal dalam pengawasan pengelolaan APBDes. Terdapat beberapa kendala yang dialami dalam pelaksanaan pengawasan ini, misalnya, kurangnya kerja sama antar anggota BPD dan kurangnya kesadaran anggota BPD dalam melaksanakan fungsi dan tanggung jawabnya pelaksana fungsi pengawasan. Hal serupa juga diteliti oleh Fauzan (2010) yang menemukan bahwa fungsi legislasi BPD belum dapat berjalan secara maksimal akibat kurang komprehensifnya pelaksanaan peran BPD di Kecamatan Wanasari dalam membingkai peraturan-peraturan desa yang masih bersifat konvensional atau menjadi kebiasaan ke dalam bentuk peraturan-peraturan yang tidak tertulis.

Penelitian ini penting dilakukan dalam era penyaluran dana desa dewasa ini, dengan mempertimbangkan bahwa kurang optimalnya peran dan fungsi BPD dalam hal pengawasan pengelolaan keuangan dapat berdampak kepada munculnya penyelewengan atas pengelolaan dana desa dan rendahnya kinerja para perangkat desa. Ketiadaan aspek pengawasan dan evaluasi diakui memang dapat menghambat implementasi pengelolaan dana desa secara lebih baik (Artini et al., 2018; Prasetya et al., 2018; Warsono dan Ruksamin, 2014). Fakta di lapangan menunjukkan bahwa paling tidak telah tercatat adanya 214 kasus penyelewengan dana desa sejak 2012-2017 dengan total kerugian negara mencapai $\mathrm{Rp}$ 46 miliar. Khusus di Kabupaten Buleleng Bali, Tim Penyidik Kepolisian Resort Buleleng telah menangani kasus 10 orang 
Kepala Desa yang tersandung kasus dugaan korupsi, dimana empat diantaranya sudah ditetapkan menjadi tersangka. Keempat kepala desa atau di Bali dikenal dengan istilah perbekel yang statusnya sudah menjadi tersangka tersebut adalah Perbekel Tinggar Sari, Perbekel Alas Angker, Perbekel Tirta Sari, dan Perbekel Rangdu (Antara Bali, 2010). Sementara itu, pada tahun 2017, Kejaksanaan Negeri Singaraja juga telah melakukan penyelidikan terhadap pengelolaan dana desa di Desa Dencarik dengan menahan Perbekel Desa Dencarik (Radar Buleleng, 2017).

\section{TINJAUAN TEORITIS}

\section{Teori Peran (Role Theory)}

Terminologi "peran" (role) sebagai sebuah konsep sosiologis pertama kali muncul pada tahun 1930-1940 melalui karyakarya pemikir klasik seperti George Herbert Mead, Ralph Linton, dan Jacob Moreno. Mead (1934) melalui perspektif interaksionis simbolisnya berfokus pada peran dari faktor-faktor individual, evolusi peran melalui interaksi sosial, serta berbagai bentuk konsep kognitif dengan mana aktor-aktor sosial memahami dan menginterpretasikan pedoman perilaku bagi dirinya sendiri dan orang lain. Sementara itu, Linton (1936) menggunakan pendekatan struktural untuk menjelaskan karakteristik perilaku seseorang yang menempati posisi sosial tertentu dalam suatu sistem sosial yang mapan. "Peran" selanjutnya dikonsepsikan sebagai ekspektasi-ekspektasi normatif yang dipegang teguh dan menjadi landasan terciptanya perilaku-perilaku tersebut. Di sisi lain, pemikiran Moreno (1934) bertolak pada hubungan-hubungan antara ekspektasi peran dan perilaku, kondisi-kondisi sosial yang memunculkan ekspektasi tersebut, serta cara-cara dengan mana seseorang mempersepsikan ekspektasi orang lain dan memahami pengaruhnya terhadap perilaku.

Teori Peran secara umum berfokus pada salah satu karakteristik paling penting dari perilaku sosial, yaitu fakta bahwa manusia berperilaku dalam cara-cara yang berbeda dan dapat diprediksi tergantung dari situasi dan identitas-identitas sosial yang dimilikinya masing-masing (Biddle, 1986). Teori ini menjelaskan konsep peran dengan asumsi awal bahwa orang-orang merupakan bagian integral dari posisiposisi sosial tertentu yang memegang ekspektasi atas perilaku-perilaku mereka sendiri dan atas perilaku-perilaku orang lain di sekitarnya. Ekspektasi selanjutnya dimaknai sebagai keyakinan-keyakinan seseorang terkait perilaku pribadinya sekaligus keyakinan-keyakinan seseorang yang diatribusikan atau dilekatkan kepada orang lain. Selain itu, peran juga dikatakan merupakan cerminan posisi seseorang dalam suatu sistem sosial sekaligus pula hak dan kewajiban serta kekuasaan dan tanggung jawab yang menyertainya (Agustina, 2009). Interaksi antar individu dalam sistem sosial ini kemudian terjadi melalui cara-cara tertentu dengan memainkan masing-masing peran yang dimiliki dalam rangka mengantisipasi perilaku orang lain di lingkungannya.

Beberapa peneliti telah mengaplikasikan konsep-konsep pada Teori Peran dalam menjelaskan adanya hubungan antara peran yang dirasakan dan dilekatkan pada diri seseorang dengan pelaksanaan tugas dan fungsi yang diemban di lingkungan pekerjaannya. Agustina (2009) menemukan bahwa adanya konflik peran (role conflict), ketidakjelasan peran (role ambiguity) dan kelebihan-kapasitas peran (role overload) dapat menurunkan tingkat kepuasan dan kualitas kinerja akuntan pada Kantor Akuntan Publik di wilayah DKI Jakarta. Pada penelitian berbeda, Ebimobowei dan Kereotu (2011) mengamati munculnya fenomena kesenjangan-harapan peran pengauditan (audit expectation gap) antara auditor internal dengan pihak manajemen dan pemilik perusahaan-perusahaan besar di Nigeria. Pada satu sisi, pihak manajemen dan pemilik perusahaan memiliki ekspektasi tinggi atas peran pencegahan kecurangan keuangan yang dimiliki auditor 
internal, namun pada sisi yang berbeda, pihak auditor internal tidak meyakini peran yang dilekatkan kepadanya tersebut. Penelitian tersebut juga menemukan bahwa rendahnya keyakinan peran oleh pihak auditor internal secara signifikan terkait langsung dengan tingkat keberhasilan pelaksanaan pekerjaan audit yang juga rendah.

\section{Kesenjangan Harapan (Expectation-Gap) dalam Konteks Akuntansi}

Dalam literatur Akuntansi, konsep kesenjangan harapan sebagian besar terkait dengan peran dan fungsi pengawasan auditor internal dalam organisasi. Porter et al. (2012) memaknai audit expectation-gap (AEG) sebagai kesenjangan antara tanggung jawab-tanggung jawab yang diharapkan oleh masyarakat dapat dilakukan oleh auditor dan tanggung jawab-tanggung jawab yang auditor yakini sebagai tanggung jawab sejati mereka. Masoud (2017) mendefinisikan AEG sebagai kesenjangan antara ekspektasi masyarakat atas kinerja auditor dan kinerja aktual yang ditampilkan oleh auditor, sebagaimana dipersepsikan oleh masyarakat.

Bentuk kesenjangan-harapan ini memiliki dua komponen utama (Porter, 1993), yaitu a) suatu kesenjangan antara tugastugas yang masyarakat harapkan untuk dapat dicapai oleh auditor dan tugas-tugas yang secara wajar memang pantas masyarakat harapkan untuk dapat dicapai oleh auditor kesenjangan kewajaran (reasonableness gap); dan 2) suatu kesenjangan antara tugas-tugas yang secara wajar memang pantas masyarakat harapkan untuk dapat dicapai oleh auditor dan tugas-tugas yang auditor persepsikan dapat mereka capai Kesenjangan Kinerja (performance gap). Komponen 'Kesenjangan Kinerja' kemudian dapat dibagi lagi menjadi a) suatu kesenjangan antara tugas-tugas yang dapat secara wajar diharapkan dilakukan oleh auditor dan tugas-tugas sejati auditor sebagaimana didefinisikan dalam peraturan-peraturan hukum dan keprofesian yang berlaku defi- cient standards; dan b) suatu kesenjangan antara tingkat standar kinerja atas pelaksanaan tugas-tugas sejati auditor dan tingkat kinerja yang dipersepsikan oleh auditor, sebagaimana diekspektasikan oleh masyarakat deficient performance. Secara diagrammatis, struktur dari kesenjangan-harapan audit ini ditampilkan pada Gambar 1.

\section{Kesenjangan Harapan (Expectation-Gap) Fungsi Pengawasan Pengelolaan Keuang- an Desa}

Sebagaimana dijelaskan dalam Teori Peran, setiap individu dalam suatu institusi atau organisasi akan mengambil satu bagian atau peran yang harus dimainkan dalam rangka memenuhi ketentuan-ketentuan dari pekerjaan yang dibebankan kepadanya. Peran-peran ini juga akan menjadi penciri dari bentuk-bentuk spesifik perilaku yang harus ditampilkan terkait pelaksanaan pekerjaan tersebut serta terkait erat dengan interaksi-interaksi sosial yang terjadi dengan pihak-pihak yang dapat terpengaruh oleh pekerjaan yang dilakukannya (Ebimobowei dan Kereotu, 2011). Dalam konteks pengelolaan keuangan desa, Badan Permusyawaratan Desa (BPD) telah dibebani fungsi dan peran pengawasan berdasarkan Permendagri 110/2016 dan dengan demikian telah dibekali ketentuanketentuan pekerjaan yang harus dipenuhi dalam pelaksanaan peran dan fungsinya tersebut.

Dalam hal ini, BPD akan memiliki keyakinan bahwa setiap pekerjaan yang dilakukan harus dan hanya akan berdasarkan ketentuan-ketentuan tersebut, namun demikian, pihak-pihak terkait, misalnya masyarakat desa, bisa jadi menaruh harapan dan ekspektasi lebih atas peran BPD dalam pengawasan pengelolaan keuangan desa. Hal ini cukup beralasan mengingat keterbatasan pengetahuan yang umumnya dimiliki oleh masyarakat desa sehingga akhirnya mempersepsikan bahwa segala hal terkait penjaminan pengelolaan keuangan desa yang baik merupakan peran dan fungsi dari BPD. 


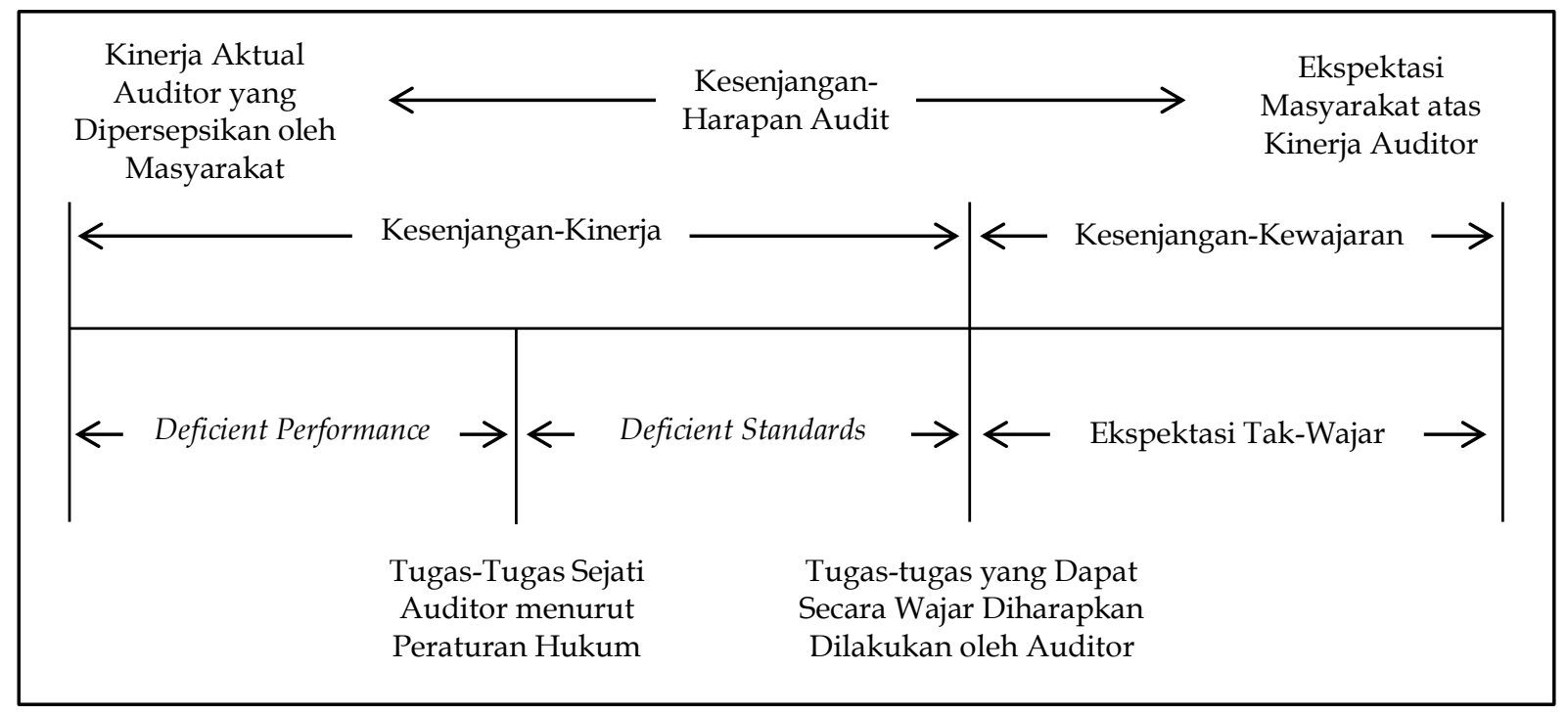

Gambar 1

Struktur Kesenjangan-Harapan Audit (Audit Expectation Gap) (Porter, 1993)

Dalam konteks pemeriksaan keuangan oleh pihak auditor, beberapa peneliti telah menemukan bukti empiris munculnya fenomena expectation-gap. Masoud (2017) menemukan bahwa terdapat kesenjanganharapan antara auditor internal dan pengguna laporan keuangan akibat adanya kesenjangan pengetahuan terkait tanggung jawab auditor, kesenjangan atas penilaian kinerja auditor dan kesenjangan atas prosedur pelaksanaan kinerja auditor. Pada penelitian berbeda, Ebimobowei dan Kereotu (2011) mendapati bahwa pihak manajemen dan pemilik perusahaan memiliki ekspektasi tinggi atas peran pencegahan kecurangan keuangan yang dimiliki auditor internal, namun pada sisi yang berbeda, pihak auditor internal tidak meyakini peran yang dilekatkan kepadanya tersebut. Selain itu, Pongsapan (2012) yang melakukan penelitian dalam konteks sektor publik di Indonesia menemukan bahwa pengguna laporan keuangan organisasi sektor publik memiliki pemahaman yang lebih tinggi terkait peran pemeriksaan oleh Badan Pemeriksa Keuangan (BPK) dibandingkan pemahaman yang dimiliki oleh BPK itu sendiri. Dengan demikian, mempertimbangkan keselarasan peran dan fungsi yang dimiliki oleh BPD dan auditor internal perusahaan dan auditor BPK, fenomena expectation gap juga patut diduga dapat muncul dalam konteks pengawasan pengelolaan keuangan desa. Penelitian ini selanjutnya mengajukan hipotesis $\mathrm{H}_{1}$ sebagai berikut:

$\mathrm{H}_{1}$ : Terdapat fenomena expectation gap antara pihak-pihak terkait dan BPD mengenai fungsi dan peran pengawasan yang dimiliki oleh BPD.

\section{Ekspektasi Fungsi Pengawasan dan Kinerja Pengawasan Pengelolaan Keua- ngan Desa}

Srikanth dan Jomon (2013) mengungkapkan bahwa keyakinan individu atas kapabilitas yang dimiliki untuk dapat secara efektif menjalankan peran yang dimilikinya dapat berpengaruh terhadap kualitas kinerja individu tersebut. Dengan kata lain, ketika terjadi ambiguitas atas peran yang dimiliki, maka hal ini akan memunculkan rasa cemas dan berujung pada penurunan produktivitas kinerja. Beberapa peneliti juga menemukan bahwa ambiguitas peran berhubungan negatif dengan kinerja auditor (Fisher, 2001) dan juga berhubungan negatif dengan kinerja manajerial dalam hal perencanaan dan pembuatan keputusan-keputusan strategis 
(Burney dan Widener, 2007). Sementara itu, Kahn et al. (1964) mengungkapkan bahwa jika peran dan tanggung jawab seseorang begitu terkait langsung dengan peran dan tanggung jawab orang lain, maka dampak dari ambiguitas peran akan semakin terasa dalam menurunkan kualitas kinerja orang tersebut. Kondisi ini tampak serupa dengan yang terjadi pada peran dan fungsi pengawasan oleh BPD dalam konteks Indonesia dengan mana terdapat beberapa pihak lain yang dibebani fungsi dan peran yang tak jauh berbeda dengan peran dan fungsi dari BPD. Dengan demikian, patut diyakini bahwa BPD pun mengalami kondisi ambiguitas peran sehingga keyakinan yang memadai atas pelaksanaan perannya dapat diduga akan sejalan dengan kualitas kinerja yang akan ditunjukkan. Penelitian ini selanjutnya mengajukan hipotesis $\mathrm{H}_{2}$ sebagai berikut:

$\mathrm{H}_{2}$ : Terdapat hubungan positif antara ekspektasi fungsi pengawasan yang dimiliki BPD dan kinerja pengawasan pengelolan keuangan oleh BPD

\section{METODE PENELITIAN Rancangan Penelitian}

Penelitian ini menggunakan pendekatan penelitian kuantitatif dengan metode survei. Pada metode survei, data diperoleh melalui penyebaran instrumen kepada responden representatif yang di-sampling dari populasi (Williams, 2007). Instrumen yang digunakan pada penelitian ini berupa kuesioner yang didistribusikan kepada kelompok responden pada kantor Inspektorat Kabupaten, kelompok Camat dan pada kelompok anggota BPD serta masyarakat pada 60 desa di sembilan kecamatan di wilayah Kabupaten Buleleng, Provinsi Bali, yaitu di Kecamatan Banjar, Buleleng, Busung Biu, Gerokgak, Kubutambahan, Sawan, Seririt, Sukasada dan Tejakula. Besaran jumlah desa yang dijadikan sampel ini diperoleh dari hasil penghitungan Rumus Slovin, dengan ukuran populasi yaitu sejumlah 129 desa di Kabupaten
Buleleng. Hasil uji beda non-parametrik Kruskal Wallis menunjukkan bahwa tidak ditemukan adanya perbedaan signifikan jawaban responden berdasarkan kecamatan ( $p$-value $>0.05)$ sehingga dapat dinyatakan bahwa perbedaan lokasi (kecamatan) tidak berpengaruh terhadap perbedaan jawaban responden. Kuesioner diantar dan diambil langsung oleh peneliti dalam rangka memastikan tingkat penerimaan dan pengembalian instrumen yang memadai. Sejumlah 654 eksemplar kuesioner (10 eksemplar untuk masing-masing desa, 9 eksemplar untuk Camat dan 45 eksemplar kuesioner untuk auditor pada Inspektorat Kabupaten Buleleng) didistribusikan dan kembali dalam jumlah yang sama (response rate $=$ 100\%). Dari jumlah tersebut sebanyak 109 diisi secara tidak lengkap oleh responden sehingga menghasilkan 545 eksemplar yang memenuhi syarat untuk diuji pada tahap analisis data (usable response rate $=83,33 \%$ ).

Sebagaimana disajikan pada Tabel 1, secara deskriptif mayoritas responden kelompok anggota BPD (38,3\%), kelompok masyarakat $(26,3 \%)$ dan kelompok Camat $(77,8 \%)$ berusia antara $40-50$ tahun, sementara untuk kelompok anggota Inspektorat Kabupaten berusia antara 30-40 tahun $(45,8 \%)$. Tingkat pendidikan terakhir jenjang SD/SMP/SMA/sederajat mendominasi pada kelompok anggota BPD (61,7\%), kelompok masyarakat $(70,7 \%)$ dan kelompok Camat $(55,6 \%)$, sementara kelompok anggota Inspektorat Kabupaten sebagian besar memiliki jenjang pendidikan terakhir setingkat program Strata-1 (S1). Untuk sebaran gender, mayoritas responden pada kelompok anggota BPD (90,5\%), kelompok masyarakat $(71,8 \%)$ dan kelompok Camat berjenis kelamin laki-laki, sedangkan sejumlah $62,5 \%$ responden pada kelompok anggota Inspektorat Kabupaten berjenis kelamin perempuan.

\section{Definisi Operasional dan Pengukuran Variabel}

Terdapat tiga kategori peran dan fungsi pengawasan pengelolaan keuangan desa 
sebagai variabel bebas yang dioperasionalisasikan pada penelitian ini. Untuk masing-masing kategori, responden diminta memberikan persetujuan mengenai ketepatan peran dan fungsi tersebut untuk di- lekatkan pada BPD dengan memberikan jawaban "ya" (skor 1) atau "tidak" (skor -1) (Porter et al., 2012). Hal ini akan menjadi ukuran atas ekspektasi responden terhadap peran pengawasan BPD.

Tabel 1

Statistika Deskriptif Demografi Responden

\begin{tabular}{|c|c|c|c|c|c|c|c|c|}
\hline \multirow{3}{*}{$\begin{array}{l}\text { Aspek Demografis } \\
\text { Usia (tahun) }\end{array}$} & \multicolumn{8}{|c|}{ Kelompok Responden } \\
\hline & \multicolumn{2}{|c|}{ Anggota BPD } & \multicolumn{2}{|c|}{ Masyarakat } & \multicolumn{2}{|c|}{ Camat } & \multicolumn{2}{|c|}{$\begin{array}{l}\text { Inspektorat } \\
\text { Kabupaten }\end{array}$} \\
\hline & & & & & & & & \\
\hline$<20$ & 1 & $(0,4)^{\mathrm{a}}$ & 11 & $(4,2)$ & 0 & $(0)$ & 12 & $(2,2)$ \\
\hline$>20-30$ & 12 & $(4,7)$ & 58 & $(22,4)$ & 0 & $(0)$ & 70 & $(12,8)$ \\
\hline$>30-40$ & 61 & $(24,1)$ & 63 & $(24,3)$ & 1 & $(11,1)$ & 136 & $(25,0)$ \\
\hline$>40-50$ & 97 & $(38,3)$ & 68 & $(26,3)$ & 7 & $(77,8)$ & 175 & $(32,1)$ \\
\hline$>50$ & 82 & $(32,4)$ & 59 & $(22,8)$ & 1 & $(11,1)$ & 152 & $(27,9)$ \\
\hline \multicolumn{9}{|l|}{ Tingkat Pendidikan } \\
\hline Tidak Bersekolah & 1 & $(0,4)$ & 3 & $(1,2)$ & 0 & $(0)$ & 0 & $(0)$ \\
\hline SD/SMP/SMA sederajat & 156 & $(61,7)$ & 183 & $(70,7)$ & 5 & $(55,6)$ & 0 & (0) \\
\hline Diploma & 16 & $(6,3)$ & 26 & $(10,0)$ & 0 & $(0)$ & 2 & $(8,3)$ \\
\hline Strata-1 & 75 & $(29,6)$ & 43 & $(16,6)$ & 4 & $(44,4)$ & 20 & $(83,3)$ \\
\hline Strata-2 & 5 & $(2,0)$ & 4 & $(1,5)$ & 0 & $(0)$ & 2 & $(8,3)$ \\
\hline \multicolumn{9}{|l|}{ Gender } \\
\hline Laki-laki & 229 & $(90,5)$ & 186 & $(71,8)$ & 9 & $(100)$ & 9 & $(37,5)$ \\
\hline Perempuan & 24 & $(9,5)$ & 73 & $(28,2)$ & 0 & $(0)$ & 15 & $(62,5)$ \\
\hline
\end{tabular}

a nilai dalam tanda kurung adalah persentase jumlah responden

Ketiga kategori peran dan fungsi pengawasan pengelolaan keuangan desa tersebut yaitu: a) Peran Pengawasan BPD (PPBPD), didefinisikan sebagai peran dan fungsi yang sebenar-benanya wajib dijalankan oleh BPD sesuai dengan peraturanperaturan yang diterbitkan pemerintah. Terdapat lima pernyataan peran yang menjadi indikator dari variabel ini, yaitu (i) membahas dan menyepakati rancangan peraturan desa bersama kepala desa; (ii) melaksanakan pengawasan terhadap kinerja kepala desa; (iii) melaksanakan monitoring dan evaluasi perencanaan kegiatan pemerintah desa; (iv) melaksanakan monitoring dan evaluasi pelaksanaan kegiatan pemerintah desa; dan (v) melaksanakan monitoring dan evaluasi pelaporan penyelenggaraan pemerintah desa. Pengujian pendahuluan mengindikasikan bahwa seluruh item pernyataan terkait variabel ini telah valid (Pearson Correlation berkisar antara $0,594-0,749 ; p$-value $=0,000)$ dan reliabel (Cronbach's Alpha $=0,677)$. Item-item pertanyaan kuesioner terkait kategori ini bersumber dari Peraturan Menteri Dalam Negeri Republik Indonesia Nomor 110 Tahun 2016 tentang Badan Permusyawaratan Desa. b) Peran Pengawasan NonBPD (PPNBPD), didefinisikan sebagai peran dan fungsi yang tidak semestinya dijalankan oleh BPD atau tidak sesuai dengan peraturan-peraturan yang diterbitkan pemerintah untuk BPD, namun ditujukan untuk lembaga pengawasan selain BPD. Terdapat empat pernyataan peran yang menjadi indikator dari variabel ini, yaitu (i) melaksanakan pengawasan terhadap kebijakan pemerintah desa; (ii) melaksanakan pengawasan terhadap kelembagaan peme- 
rintah desa; (iii) melaksanakan pengawasan terhadap keuangan pemerintah desa; dan (iv) melaksanakan pengawasan terhadap kekayaan pemerintah desa. Pengujian pendahuluan mengindikasikan bahwa seluruh item pernyataan terkait variabel ini telah valid (Pearson Correlation berkisar antara $0,613$ - 0,793; p-value $=0,000)$ dan reliabel (Cronbach's Alpha $=0,711)$. Item-item pertanyaan kuesioner terkait kategori ini bersumber dari Peraturan Menteri Dalam Negeri Nomor 7 Tahun 2008 tentang Pedoman Tata Cara Pengawasan atas Penyelenggaraan Pemerintahan Desa. c) Peran Pengawasan Melebihi Kapasitas BPD (PPMKBPD), didefinisikan sebagai ekspektasi-ekspektasi irasional dari pihak-pihak berkepentingan atas peran pengawasan yang seharusnya dijalankan oleh BPD. Terdapat lima pernyataan peran yang menjadi indikator dari variabel ini, yaitu (i) membuat laporan keuangan pemerintah desa; (ii) mendeteksi adanya korupsi yang dilakukan oleh perangkat desa; (iii) mendesain sistem pembukuan dan sistem laporan keuangan pemerintah desa; (iv) mengungkapkan setiap kesalahan dalam pengelolaan aset desa; dan (v) mendesain sistem pengendalian internal pemerintahan desa. Pengujian pendahuluan mengindikasikan bahwa seluruh item pernyataan terkait variabel ini telah valid (Pearson Correlation berkisar antara 0,642 $0,800 ; \quad p$-value $=0,000)$ dan reliabel (Cronbach's Alpha $=0,794$ ). Kuesioner yang digunakan terkait kategori ini diadaptasi dan dimodifikasi dari instrument penelitian Ebimobowei dan Kereotu (2011), Pongsapan (2012) dan Porter et al. (2012). Modifikasi minor dilakukan terutama dalam hal tata bahasa sehingga responden dapat lebih memahami maksud pertanyaan yang diberikan.

Sementara itu, variabel terikat yang dioperasionalkan pada penelitian ini adalah Kinerja Pengawasan Persepsian BPD (KPPBPD), yaitu kualitas kinerja persepsional atas peran dan fungsi yang sebenarbenarnya wajib dijalankan oleh BPD sesuai dengan peraturan-peraturan yang diterbitkan pemerintah. Pengukuran atas variabel ini ditujukan untuk responden kelompok anggota BPD dengan mana responden di minta memberikan penilaian terhadap kualitas kinerja personal sehubungan dengan pelaksanaan peran dan fungsi pengawasan yang diemban sesuai dengan peraturan-peraturan yang diterbitkan pemerintah (dengan kata lain, kategori Peran Pengawasan BPD). Variabel ini diukur menggunakan skala pengukuran bertipe Likert empat poin $(0=$ "Tidak Dapat Ditentukan", 1 = "Buruk", 2 = "Cukup" dan 3 $=$ "Baik") sebagaimana diadaptasi dari instrumen dan cara pengukuran yang digunakan oleh Porter et al. (2012). Pengujian pendahuluan mengindikasikan bahwa seluruh item pernyataan terkait variabel ini telah valid (Pearson Correlation berkisar antara 0,612 - 0,736; p-value $=0,000)$ dan reliabel (Cronbach's Alpha $=0,701$ ).

\section{Teknik Analisis Data}

Mempertimbangkan bahwa data penelitian yang digunakan merupakan data kategorikal dan asumsi normalitas data tidak dapat diyakini mampu terpenuhi, pengujian atas hipotesis $\mathrm{H}_{1}$ dilakukan menggunakan teknik analisis uji beda kelompok sampel non-parametrik The Mann-Whitney test. Teknik pengujian ini dapat digunakan untuk mengetahui perbedaan jawaban dua kelompok sampel berbeda ketika variabel-variabel yang diukur bertipe ordinal dan diukur dengan skala pengukuran yang tidak terlalu presisi (Nachar, 2008). Sementara itu, pengujian untuk hipotesis $\mathrm{H}_{2}$ dilakukan dengan menggunakan teknik analisis Ordinal Regression Analysis. Teknik pengujian ini digunakan untuk menguji hubungan antar variabel ketika variabel terikat yang dioperasionalisasikan diukur dalam skala kategorikal yang bertingkat (misalnya menggunakan skala pengukuran bertipe Likert) dengan mana asumsi normalitas dan homogenitas tidak dapat dipenuhi secara meyakinkan (Elamir dan Sadeq, 2010). 


\section{ANALISIS DAN PEMBAHASAN Analisis Statistika Deskriptif}

Hasil analisis statistika deskriptif variabel penelitian (Tabel 2) mengindikasikan bahwa rata-rata responden kelompok anggota BPD memberikan nilai persepsian yang tinggi terkait kinerja pengawasan pengelolaan keuangan desa yang dilakukannya (rentang nilai aktual minimal 7,00 dan maksimal 15,00 serta mean $=13,7905)$. Sementara itu, untuk indikator peran pengawasan BPD (PPBPD), rata-rata responden telah secara tepat mengidentifikasikan pernyataan-pernyataan pada indikator tersebut sebagai peran sesungguhnya dari BPD (mean bernilai positif 4,2917). Di sisi lain, untuk indikator peran pengawasan non-BPD juga diperoleh besaran mean bernilai positif $(2,8642)$ yang justru mengindikasikan bahwa rata-rata responden secara tidak tepat telah mengekspektasikan peran pengawasan lembaga non-BPD sebagai peran pengawasan dari BPD. Menariknya, rata-rata responden terindikasi mengalami kebimbangan ketika diminta menetapkan pernyataan-pernyataan peran pengawasan pada indikator Peran Melebihi Kapasitas BPD sebagai peran pengawasan dari BPD dengan mean $(-0,6037)$ yang mendekati nilai tengah 0,00 .

Tabel 2

Statistika Deskriptif Variabel Penelitian

\begin{tabular}{lcccccc}
\hline \hline \multirow{2}{*}{ Variabel } & \multicolumn{2}{c}{ Rentang NIlai Teoretis } & \multicolumn{2}{c}{ Rentang Nilai Aktual } & \multirow{2}{*}{ Mean } & \multirow{2}{*}{ Std. Deviation } \\
\cline { 2 - 5 } & Min & Maks & Min & Maks & & \\
\hline KPPBPD & 0,00 & 15,00 & 7,00 & 15,00 & 13,7905 & 1,89600 \\
PPBPD & $-5,00$ & 5,00 & $-5,00$ & 5,00 & 4,2917 & 1,68176 \\
PPNBPD & $-4,00$ & 4,00 & $-4,00$ & 4,00 & 2,8642 & 2,02464 \\
PPMKBPD & $-5,00$ & 5,00 & $-5,00$ & 5,00 & $-0,6037$ & 3,41988 \\
\hline
\end{tabular}

Keterangan: KPPBPD=Kinerja Pengawasan Persepsian BPD; PPBPD=Peran Pengawasan BPD; PPNBPD=Peran Pengawasan Non-BPD; PPMKBPD=Peran Pengawasan Melebihi Kapasitas BPD

\section{Pengujian Hipotesis}

Pengujian Hipotesis $\mathrm{H}_{1}$

Hipotesis $\mathrm{H}_{1}$ memprediksi munculnya fenomena expectation gap antara BPD dan pihak-pihak terkait mengenai fungsi dan peran pengawasan yang dimiliki oleh BPD. Tabel 3 menampilkan hasil uji MannWhitney test jawaban kelompok responden anggota BPD dan masyarakat per kategori peran pengawasan BPD. Hasil pengujian mengindikasikan adanya perbedaan signifikan terkait ekspektasi yang dimiliki kedua kelompok responden tersebut pada kategori PPBPD (p-value $=0,000)$ dan kategori PPM$\operatorname{KBPD}(p$-value $=0,000)$, namun tidak signifikan pada kategori PPNBPD ( $p$-value > $0,05)$.

Selanjutnya, Tabel 4 secara rinci menyajikan hasil uji Mann-Whitney test terkait perbedaan harapan antara kelompok anggota BPD dan masyarakat atas peran pengawasan keuangan desa per indikator. Perbedaan signifikan ditemukan pada empat dari lima pernyataan PPBPD (PPBPD 1, PPBPD 3, PPBPD 4, dan PPBPD 5) serta empat dari lima pernyataan PPMKBPD (PPMKBPD 1, PPMKBPD 3, PPMKBPD 4, dan PPMKBPD 5). Tabel 5 menampilkan hasil uji Mann-Whitney test jawaban kelompok responden anggota BPD dan Camat per kategori peran pengawasan BPD.

Hasil pengujian mengindikasikan adanya perbedaan signifikan terkait ekspektasi yang dimiliki kedua kelompok responden tersebut pada kategori PPMKBPD (p-value = $0,008)$, namun tidak signifikan pada kategori kategori PPBPD ( $p$-value $>0,05$ ) dan PPNBPD ( $p$-value $>0,05)$. 
Tabel 3

Hasil Uji Beda Non-Parametrik Mann-Whitney test Anggota BPD dan Masyarakat per Kategori

\begin{tabular}{cccccc}
\hline \hline \multirow{2}{*}{ No. } & \multirow{2}{*}{ Kategori } & \multicolumn{2}{c}{ Mean Rank Kelompok } & \multirow{2}{*}{ Signifikansi } & $\begin{array}{c}\text { Perbedaan } \\
\text { Signifikan? }\end{array}$ \\
\cline { 3 - 4 } & & Anggota BPD & Masyarakat & & Ya \\
\hline 1 & PPBPD & 272,85 & 240,53 & 0,000 & Ya \\
2 & PPNBPD & 254,07 & 258,87 & 0,653 & Tidak \\
3 & PPMKBPD & 220,85 & 291,33 & 0,000 & Ya
\end{tabular}

Selanjutnya, Tabel 6 secara rinci menyajikan hasil uji Mann-Whitney test terkait perbedaan harapan antara kelompok anggota BPD dan Camat atas peran pengawasan keuangan desa per indikator.
Perbedaan signifikan ditemukan pada tiga dari empat pernyataan PPNBPD (PPNBPD 1, PPNBPD 2, dan PPNBPD 3) serta dua dari lima pernyataan PPMKBPD (PPMKBPD 1 dan PPMKBPD 3).

Tabel 4

Hasil Uji Beda Non-Parametrik Mann-Whitney test Anggota BPD dan Masyarakat per Indikator

\begin{tabular}{|c|c|c|c|c|c|c|c|}
\hline \multirow{2}{*}{ No. } & \multirow{2}{*}{ Indikator } & \multicolumn{2}{|c|}{$\begin{array}{c}\text { Jumlah Jawaban } \\
\text { "Benar"(a) }\end{array}$} & \multicolumn{2}{|c|}{$\begin{array}{c}\text { Mean Rank } \\
\text { Kelompok }\end{array}$} & \multirow{2}{*}{ Sig. } & \multirow{2}{*}{$\begin{array}{l}\text { Perbedaan } \\
\text { Signifikan? }\end{array}$} \\
\hline & & $\begin{array}{l}\text { Anggota } \\
\text { BPD }\end{array}$ & Masyarakat & $\begin{array}{l}\text { Anggota } \\
\text { BPD }\end{array}$ & Masyarakat & & \\
\hline 1 & PPBPD_1 & $99,2 \%$ & $95,4 \%$ & 261,48 & 251,64 & 0,008 & Ya \\
\hline 2 & PPBPD_2 & $97,6 \%$ & $95,0 \%$ & 259,93 & 253,15 & 0,113 & Tidak \\
\hline 3 & PPBPD_3 & $94,1 \%$ & $86,5 \%$ & 266,32 & 246,91 & 0,004 & Ya \\
\hline 4 & PPBPD_4 & $93,3 \%$ & $87,3 \%$ & 264,30 & 248,88 & 0,022 & $\mathrm{Ya}$ \\
\hline 5 & PPBPD_5 & $92,5 \%$ & $86,1 \%$ & 264,77 & 248,42 & 0,020 & Ya \\
\hline 6 & PPNBPD_1 & $5,5 \%$ & $8,1 \%$ & 259,83 & 253,24 & 0,249 & Tidak \\
\hline 7 & PPNBPD_2 & $15,0 \%$ & $10,8 \%$ & 250,59 & 262,27 & 0,126 & Tidak \\
\hline 8 & PPNBPD_3 & $17,0 \%$ & $18,1 \%$ & 257,99 & 255,04 & 0,733 & Tidak \\
\hline 9 & PPNBPD_4 & $20,9 \%$ & $18,9 \%$ & 253,87 & 259,07 & 0,566 & Tidak \\
\hline 10 & PPMKBPD_1 & $90,9 \%$ & $69,5 \%$ & 228,77 & 283,58 & 0,000 & Ya \\
\hline 11 & PPMKBPD_2 & $37,5 \%$ & $30,9 \%$ & 247,87 & 264,93 & 0,112 & Tidak \\
\hline 12 & PPMKBPD_3 & $88,1 \%$ & $67,6 \%$ & 229,86 & 282,53 & 0,000 & Ya \\
\hline 13 & PPMKBPD_4 & $44,3 \%$ & $32,4 \%$ & 241,17 & 271,47 & 0,006 & Ya \\
\hline 14 & PPMKBPD_5 & $75,9 \%$ & $52,1 \%$ & 225,72 & 286,56 & 0,000 & Ya \\
\hline
\end{tabular}

Tabel 7 menampilkan hasil uji MannWhitney test jawaban kelompok responden anggota BPD dan Inspektorat per kategori peran pengawasan BPD. Hasil pengujian mengindikasikan adanya perbedaan signifikan terkait ekspektasi yang dimiliki kedua kelompok responden tersebut pada PPBPD $(p$-value $>0,045)$, kategori PPMKBPD ( $p$ - value $=0,001)$, dan kategori PPNBPD ( $p$ value $=0,000)$. Selanjutnya, Tabel 8 secara rinci menyajikan hasil uji Mann-Whitney test terkait perbedaan harapan antara kelompok anggota BPD dan Inspektorat atas peran pengawasan keuangan desa per indikator. Perbedaan signifikan ditemukan pada empat dari lima pernyataan PPNBPD (PPN- 
BPD 2, PPNBPD 3, PPNBPD 4, dan PPNBPD 5) serta keseluruhan pernyataan PPM-
KBPD (PPMKBPD 1, PPMKBPD 2, PPMKBPD 3, PPMKBPD 4, dan PPMKBPD 5).

Tabel 5

Hasil Uji Beda Non-Parametrik Mann-Whitney test Anggota BPD dan Camat per Kategori

\begin{tabular}{cccccc}
\hline \hline \multirow{2}{*}{ No. } & \multirow{2}{*}{ Kategori } & \multicolumn{2}{c}{ Mean Rank Kelompok } & \multirow{2}{*}{ Signifikansi } & $\begin{array}{c}\text { Perbedaan } \\
\text { Signifikan? }\end{array}$ \\
\cline { 3 - 4 } & Anggota BPD & Camat & & Sidak \\
\hline 1 & PPBPD & 131,88 & 120,89 & 0,490 & Tidak \\
2 & PPNBPD & 133,46 & 76,44 & 0,008 & Ya \\
3 & PPMKBPD & 130,48 & 160,11 & 0,235 & Tidak \\
\hline
\end{tabular}

Keterangan: PPBPD=Peran Pengawasan BPD; PPNBPD=Peran Pengawasan Non-BPD; PPMKBPD=Peran Pengawasan Melebihi Kapasitas BPD

Tabel 6

Hasil Uji Beda Non-Parametrik Mann-Whitney test Anggota BPD dan Camat per Indikator

\begin{tabular}{|c|c|c|c|c|c|c|c|}
\hline \multirow{2}{*}{ No. } & \multirow{2}{*}{ Indikator } & \multicolumn{2}{|c|}{$\begin{array}{c}\text { Jumlah Jawaban } \\
\text { "Benar"(a) }\end{array}$} & \multicolumn{2}{|c|}{$\begin{array}{l}\text { Mean Rank } \\
\text { Kelompok }\end{array}$} & \multirow{2}{*}{ Sig. } & \multirow{2}{*}{$\begin{array}{l}\text { Perbedaan } \\
\text { Signifikan? }\end{array}$} \\
\hline & & $\begin{array}{l}\text { Anggota } \\
\text { BPD }\end{array}$ & Camat & $\begin{array}{l}\text { Anggota } \\
\text { BPD }\end{array}$ & Camat & & \\
\hline 1 & PPBPD_1 & $99,2 \%$ & $100,0 \%$ & 131,46 & 132,50 & 0,789 & Tidak \\
\hline 2 & PPBPD_2 & $97,6 \%$ & $88,9 \%$ & 131,89 & 120,44 & 0,111 & Tidak \\
\hline 3 & PPBPD_3 & $94,1 \%$ & $88,9 \%$ & 131,73 & 124,94 & 0,524 & Tidak \\
\hline 4 & PPBPD_4 & $93,3 \%$ & $77,8 \%$ & 132,20 & 111,89 & 0,079 & Tidak \\
\hline 5 & PPBPD_5 & $92,5 \%$ & $88,9 \%$ & 131,66 & 126,94 & 0,690 & Tidak \\
\hline 6 & PPNBPD_1 & $5,5 \%$ & $22,2 \%$ & 132,25 & 110,39 & 0,040 & Ya \\
\hline 7 & PPNBPD_2 & $15,0 \%$ & $66,7 \%$ & 133,82 & 66,33 & 0,000 & Ya \\
\hline 8 & PPNBPD_3 & $17,0 \%$ & $44,4 \%$ & 132,74 & 96,78 & 0,035 & Ya \\
\hline 9 & PPNBPD_4 & $20,9 \%$ & $44,4 \%$ & 132,56 & 101,78 & 0,094 & Tidak \\
\hline 10 & PPMKBPD_1 & $90,9 \%$ & $55,6 \%$ & 129,91 & 176,22 & 0,001 & Ya \\
\hline 11 & PPMKBPD_2 & $37,5 \%$ & $33,3 \%$ & 131,31 & 136,83 & 0,798 & Tidak \\
\hline 12 & PPMKBPD_3 & $88,1 \%$ & $55,6 \%$ & 130,03 & 172,72 & 0,004 & Ya \\
\hline 13 & PPMKBPD_4 & $44,3 \%$ & $33,3 \%$ & 131,01 & 145,33 & 0,517 & Tidak \\
\hline 14 & PPMKBPD_5 & $75,9 \%$ & $55,6 \%$ & 130,58 & 157,22 & 0,166 & Tidak \\
\hline
\end{tabular}

Tabel 7

Hasil Uji Beda Non-Parametrik Mann-Whitney test Anggota BPD dan Inpektorat per Kategori

\begin{tabular}{lccccc}
\hline \multirow{2}{*}{ No. } & \multirow{2}{*}{ Kategori } & \multicolumn{2}{c}{ Mean Rank Kelompok } & \multirow{2}{*}{ Signifikansi } & $\begin{array}{c}\text { Perbedaan } \\
\text { Signifikan? }\end{array}$ \\
\cline { 3 - 5 } & Anggota BPD & Inspektorat & & Siga \\
\hline 1 & PPBPD & 137,25 & 157,50 & 0,045 & Ya \\
2 & PPNBPD & 135,16 & 179,50 & 0,001 & Ya \\
3 & PPMKBPD & 127,76 & 257,50 & 0,000 & Ya \\
\hline Keterangan: & PPBPD=Peran & Pengawasan BPD; & PPNBPD=Peran & Pengawasan & Non-BPD; \\
PPMKBPD=Peran Pengawasan Melebihi Kapasitas BPD & & &
\end{tabular}


Tabel 8

Hasil Uji Beda Non-Parametrik Mann-Whitney test Anggota BPD dan Inspektorat per Indikator

\begin{tabular}{|c|c|c|c|c|c|c|c|}
\hline \multirow{2}{*}{ No. } & \multirow{2}{*}{ Indikator } & \multicolumn{2}{|c|}{$\begin{array}{c}\text { Jumlah Jawaban } \\
\text { "Benar"(a) }\end{array}$} & \multicolumn{2}{|c|}{$\begin{array}{c}\text { Mean Rank } \\
\text { Kelompok }\end{array}$} & \multirow{2}{*}{ Sig. } & \multirow{2}{*}{$\begin{array}{c}\text { Perbedaan } \\
\text { Signifikan? }\end{array}$} \\
\hline & & $\begin{array}{l}\text { Anggota } \\
\text { BPD }\end{array}$ & Inspektorat & $\begin{array}{l}\text { Anggota } \\
\text { BPD }\end{array}$ & Inspektorat & & \\
\hline 1 & PPBPD_1 & $99,2 \%$ & $100,0 \%$ & 138,91 & 140,00 & 0,663 & Tidak \\
\hline 2 & PPBPD_2 & $97,6 \%$ & $100,0 \%$ & 138,72 & 142,00 & 0,446 & Tidak \\
\hline 3 & PPBPD_3 & $94,1 \%$ & $100,0 \%$ & 138,29 & 146,50 & 0,221 & Tidak \\
\hline 4 & PPBPD_4 & $93,3 \%$ & $100,0 \%$ & 138,19 & 147,50 & 0,191 & Tidak \\
\hline 5 & PPBPD_5 & $92,5 \%$ & $100,0 \%$ & 138,10 & 148,50 & 0,165 & Tidak \\
\hline 6 & PPNBPD_1 & $5,5 \%$ & $0,0 \%$ & 138,48 & 146,00 & 0,238 & Tidak \\
\hline 7 & PPNBPD_2 & $15,0 \%$ & $0,0 \%$ & 137,15 & 158,50 & 0,038 & $\mathrm{Ya}$ \\
\hline 8 & PPNBPD_3 & $17,0 \%$ & $0,0 \%$ & 136,96 & 160,50 & 0,028 & $\mathrm{Ya}$ \\
\hline 9 & PPNBPD_4 & $20,9 \%$ & $0,0 \%$ & 136,49 & 165,50 & 0,013 & Ya \\
\hline 10 & PPMKBPD_1 & $90,9 \%$ & $0,0 \%$ & 128,09 & 254,00 & 0,000 & $\mathrm{Ya}$ \\
\hline 11 & PPMKBPD_2 & $37,5 \%$ & $0,0 \%$ & 134,49 & 186,50 & 0,000 & $\mathrm{Ya}$ \\
\hline 12 & PPMKBPD_3 & $88,1 \%$ & $0,0 \%$ & 128,42 & 250,50 & 0,000 & Ya \\
\hline 13 & PPMKBPD_4 & $44,3 \%$ & $0,0 \%$ & 133,69 & 195,00 & 0,000 & $\mathrm{Ya}$ \\
\hline 14 & PPMKBPD_5 & $75,9 \%$ & $0,0 \%$ & 129,89 & 235,00 & 0,000 & $\mathrm{Ya}$ \\
\hline
\end{tabular}

Berdasarkan hasil pengujian pada Tabel 3 - Tabel 8 dapat diindikasikan bahwa terdapat perbedaan ekspektasi (expectation-gap) peran pengawasan BPD antara kelompok responden anggota BPD dan pihak-pihak terkait yaitu anggota masyarakat, Camat dan anggota Inspektorat Kabupaten sehingga hipotesis $\mathrm{H}_{1}$ dapat dinyatakan terdukung oleh data empiris. Temuan ini konsisten dengan hasil penelitian Ebimobowei dan Kereotu (2011), Pongsapan (2012) dan Masoud (2017) yang menemukan munculnya fenomena expectation-gap peran pengauditan antara auditor dan pihakpihak terkait baik pada organisasi sektor swasta maupun organisasi sektor publik. Ebimobowei dan Kereotu (2011) menjelaskan bahwa fenomena ini dapat terjadi karena kelemahan dalam standar-standar kinerja (deficiency in standards) yang ditetapkan pemerintah dengan mana kinerja auditor tidak secara jelas didefinisikan atau disebutkan dalam aturan-aturan legal. Masoud (2017) menambahkan bahwa defisiensi standar juga dapat muncul pada aturan-aturan yang justru disusun secara mandiri oleh profesi sebab pihak profesi merasakan kurang kuatnya aturan legal yang menjadi dasar pemenuhan harapanharapan masyarakat atas kinerja mereka.

Selain itu, secara alamiah publik memiliki keyakinan yang begitu tinggi terhadap kelompok-kelompok profesi, namun seringkali tidak diimbangi dengan pemahaman para profesional atas standar kinerja yang dimiliki. Mayoritas publik memiliki ekspektasi bahwa pihak profesi bertanggung jawab penuh atas peran utamanya (Ebimobowei dan Kereotu, 2011), dalam konteks penelitian ini yaitu ekspektasi public terhadap anggota BPD atas peran utamanya dalam pengawasan pengelolaan keuangan desa. Kekeliruan interpretasi peran seperti ini disebabkan oleh rendahnya tingkat pengetahuan yang dimiliki oleh masyarakat atas tugas-tugas sejati dari anggota BPD yang bahkan selanjutnya dapat memunculkan ekspektasi-ekspektasi peran 
yang berlebihan dan tidak masuk akal untuk dilakukan oleh BPD (Pongsapan, 2012). Hal seperti ini terindikasi dari hasil pengujian data pada penelitian ini yang menunjukkan besaran nilai mean rank yang lebih tinggi untuk ekspektasi atas kategori Peran Pengawasan Melebihi Kapasitas BPD (PPMKBPD) kelompok masyarakat $(291,33)$ versus kelompok anggota BPD $(220,85)$ [Tabel 3], kelompok Camat $(160,11)$ versus kelompok anggota BPD $(130,48)$ [Tabel 5] dan kelompok Inspektorat $(257,50)$ versus kelompok anggota BPD $(127,76)$ [Tabel 7].

Di sisi lain, hasil penelitian juga menunjukkan bahwa kelompok masyarakat terindikasi relatif kurang memahami peran dan fungsi yang sebenar-benanya wajib dijalankan oleh BPD sesuai dengan peraturan-peraturan yang diterbitkan pemerintah. Sebagaimana ditampilkan pada Tabel 3, nilai mean rank untuk kategori PPBPD pada kelompok masyarakat $(240,53)$ lebih rendah dibandingkan dengan kelompok BPD $(272,85)$. Perbedaan nilai mean rank ini signifikan pada taraf signifikansi $\mathrm{p}<0,01$. Hal ini selaras dengan temuan pada penelitian Simbolon dan Sembiring (2015) yang mengevaluasi kinerja BPD di Desa Juhar Kecamatan Bandar Khalifah Kabupaten Serdang Bedagai Provinsi Sumatera Utara. Penelitian tersebut menemukan bahwa salah satu hambatan pelaksanaan tugastugas BPD adalah kurangnya pemahaman dan pengetahuan masyarakat terhadap peran dan fungsi yang diemban oleh BPD.

\section{Pengujian Hipotesis $\mathrm{H}_{2}$}

Hipotesis $\mathrm{H}_{2}$ memprediksi adanya hubungan positif antara ekspektasi anggota BPD atas fungsi pengawasan yang dimiliki dan kinerja pengawasan pengelolaan keuangan yang dilakukan. Pengujian dilakukan menggunakan alat analisis Ordinal Regression Analysis dengan mengoperasionalisasikan variabel Peran Pengawasan BPD (PPBPD) sebagai variabel bebas dan Kinerja Pengawasan Persepsian BPD (KPP$\mathrm{BPD})$ sebagai variabel terikat. Hasil pengujian atas kemampuan prediktif model sebagaimana ditampilkan pada Tabel 9 (ChiSquare $=9,674 ;$ p-value $=0,002)$ mengindikasikan bahwa model akhir (final model) mampu memberikan prediksi yang lebih baik dibandingkan model dasar (interceptonly model) terhadap perubahan varians yang terjadi pada variabel terikat (Elamir dan Sadeq, 2010). Dengan kata lain, model yang diajukan dapat dikatakan telah memiliki kemampuan prediktif yang memadai.

Selanjutnya, dilakukan pula pengukuran atas kehandalan model dalam menjelaskan variasi yang terjadi pada data menggunakan parameter Pseudo $R$ Square. Parameter ini dapat memberikan indikasi besaran proporsi dari variasi pada variabel terikat yang disebabkan oleh varabel bebas dengan kriteria bahwa semakin besar nilai Pseudo $R$ Square maka semakin baik pula kualitas model yang diajukan (Iyare, 2016). Di sisi lain, pengujian terhadap tingkat konsistensi antara data dan model yang diajukan juga dilakukan menggunakan parameter The Goodness-of-Fit dengan kriteria bahwa model dikatakan baik jika memiliki nilai Chi-square yang tidak signifikan (Elamir dan Sadeq, 2010). Terakhir, pengujian terhadap terpenuhinya asumsi bahwa model mengandung koefisien regresi yang setara (equal regression coefficients) dilakukan menggunakan uji Parallel Lines test dengan kriteria bahwa asumsi terpenuhi jika memiliki nilai Chi-square yang tidak signifikan (Chen dan Hughes, 2004). Berdasarkan Tabel 10, Tabel 11 dan Tabel 12, secara umum, model yang diajukan telah memenuhi kriteria kehandalan dan dapat dinyatakan konsisten (Pearson's Chi-square dan Devi-ance's Chi-square memiliki p-value $>0,05)$ serta memenuhi asumsi kesetaraan koefisien ( $p$-value's Chi-square $>0,05)$.

Tabel 13 selanjutnya menampilkan nilai-nilai estimasi parameter dan besaran pengaruh variabel bebas terhadap variabel terikat. Rule of thumb menyatakan bahwa tanda bilangan yang positif (negatif) pada nilai koefisien atau estimasi variabel bebas mengindikasikan hubungan yang bersifat searah (tidak searah) antara variabel bebas 
Tabel 9

Model Fitting Information

\begin{tabular}{lcccc}
\hline Model & -2 Log Likelihood & Chi-Square & df & Sig. \\
\hline Intercept Only & 18,681 & & & \\
Final & 9,007 & 9,674 & 1 & 0,002 \\
\hline
\end{tabular}

Link function: Complementary Log-log

Tabel 10

Pseudo R-Square

\begin{tabular}{lr}
\hline Cox and Snell & 0,038 \\
Nagelkerke & 0,058 \\
McFadden & 0,037 \\
\hline Link function: Complementary Log-log
\end{tabular}

Tabel 11

Goodness-of-Fit

\begin{tabular}{lccc}
\hline & Chi-Square & df & Sig. \\
\hline Pearson & 0,434 & 1 & 0,510 \\
Deviance & 0,484 & 1 & 0,487 \\
\hline
\end{tabular}

Link function: Complementary Log-log

Tabel 12

Test of Parallel Lines

\begin{tabular}{lcccc}
\hline Model & -2 Log Likelihood & Chi-Square & df & Sig. \\
\hline $\begin{array}{l}\text { Null Hypothesis } \\
\text { General }\end{array}$ & 9,007 & & & \\
\hline
\end{tabular}

Link function: Complementary Log-log

tersebut dan variabel terikat. Peningkatan nilai variabel bebas dengan koefisien bertanda positif menggambarkan peningkatan probabilitas variabel bebas tersebut untuk menyebabkan variabel terikat berada pada kategori yang lebih "tinggi" (dalam hal ini misalnya peningkatan kategori KPPBPD dari "Cukup" menjadi "Baik"). Demikian pula sebaliknya, peningkatan nilai variabel bebas dengan koefisien bertanda negatif menggambarkan peningkatan probabilitas variabel bebas tersebut untuk menyebabkan variabel terikat berada pada kategori yang lebih "rendah" (dalam hal ini misalnya penurunan kategori KPPBPD dari "Cukup" menjadi "Buruk").

Pada Tabel 13, besaran koefisien regresi (Estimate) variabel bebas "PPBPD bernilai-
1" (kategori "Rendah") memiliki nilai negatif $(-1,914)$ dan signifikan $(p$-value $=0,017)$ sehingga dapat diintepretasikan bahwa peningkatan nilai variabel bebas "PPBPD bernilai -1" (kategori "Rendah") terkorespondensi dengan peningkatan probabilitas variabel terikat (KPPBPD) untuk berada pada kategori yang lebih "rendah". Dengan kata lain, meningkatnya ekspektasi yang rendah atas peran pengawasan yang sejatinya memang menjadi wewenang dari anggota BPD (direpresentasikan oleh variabel bebas PPBPD kategori "Tidak") dapat menyebabkan penurunan tingkat kualitas kinerja pengawasan yang dipersepsikan oleh anggota BPD tersebut (tingkat kategori kualitas KPPBPD "menurun" atau menjadi lebih "rendah"). Jadi dapat disimpulkan bahwa 
hubungan antara variabel Peran Pengawasan BPD (PPBPD) dan variabel Kinerja Pengawasan Persepsian BPD (KPPBD) merupakan hubungan yang searah (positif) sehingga hipotesis $\mathrm{H}_{2}$ dapat dinyatakan terdukung oleh data empiris.

Tabel 13

Parameter Estimates

\begin{tabular}{llccccc}
\hline & & Estimate & Std. Error & Wald & df & Sig. \\
\hline \multirow{3}{*}{ Threshold } & {$[\mathrm{KPPBPD}=1,00]$} & $-2,121$ & 0,456 & 21,679 & 1 & 0,000 \\
& {$[\mathrm{KPPBPD}=2,00]$} & $-0,491$ & 0,079 & 39,083 & 1 & 0,000 \\
Location & {$[\mathrm{PPBPD}=-1,00]$} & $-1,914$ & 0,805 & 5,652 & 1 & 0,017 \\
& {$[\mathrm{PPBPD}=1,00]$} & 0 0 & & & 0 & \\
\hline
\end{tabular}

Link function: Complementary Log-log

a This parameter is set to zero because it is redundant

Keterangan: KPPBPD=Kinerja Pengawasan Persepsian BPD; PPBPD=Peran Pengawasan BPD.

Temuan ini konsisten dengan hasil penelitian Fisher (2001), Burney dan Widener (2007) dan Srikanth dan Jomon (2013) terkait pengaruh positif pemahaman peran dan kinerja sehubungan dengan pelaksanaan peran tersebut. Srikanth dan Jomon (2013) menyatakan bahwa untuk dapat berkinerja baik, ekspektasi-ekspekasi atas peran spesifik terkait pemenuhan kinerja tersebut perlu diketahui terlebih dahulu agar tidak memunculkan ambiguitas peran. Ambiguitas peran yang selanjutnya dimaknai sebagai minimnya informasi dan pemahaman atas tujuan-tujuan, atas kondisikondisi yang melingkupi pelaksanaan pekerjaan, dan atas tanggung jawab serta tugas-tugas yang dimiliki memang diyakini dapat menghambat efektivitas pelaksanaan kinerja individu.

Hal ini selaras dengan temuan dari penelitian Putri et al. (2017) terkait faktorfaktor anteseden efektivitas sistem pengendalian internal pemerintah desa pada desadesa se-Kabupaten Karangasem Provinsi Bali. Ditemukan bahwa aspek pengetahuan terhadap peraturan, termasuk peraturan mengenai prosedur pelaksanaan tugas monitoring dan evaluasi, memiliki pengaruh positif terhadap kualitas sistem pengendalian internal yang diterapkan dalam pengawasan pengelolaan keuangan desa. Konsep pada Teori Peran juga menyatakan bahwa orang-orang merupakan bagian integral dari posisi-posisi sosial tertentu yang memegang ekspektasi atas perilaku-perilaku mereka sendiri. Ekspektasi merupakan keyakinan-keyakinan seseorang terkait perilaku pribadinyayang selanjutnya mengarahkan bentuk-bentuk perilaku yang ditampilkan. Pada penelitian ini, hubungan positif antara ekspektasi peran dan kualitas kinerja persepsian yang dimiliki anggota BPD dapat diduga terjadi karena rata-rata anggota BPD telah mampu dengan tepat mengidentifikasi (mengekspektasikan) peran pengawasan yang memang menjadi tanggung jawabnya secara hukum (variabel bebas indikator PPBPD). Sebagaimana ditampilkan pada Tabel 3B Tabel 8, persentase hasil pengujian jumlah jawaban "benar" kelompok anggota BPD untuk kategori PPBPD mengindikasikan tingkat ekspektasi yang baik pada rentang nilai $92,5 \%$ - 99,2\%.

\section{SIMPULAN}

Penelitian ini bertujuan untuk menginvestigasi munculnya fenomena kesenjangan-harapan (expectation-gap) antara anggota Badan Permusyawaratan Desa (BPD) dan pihak-pihak terkait sehubungan dengan peran pengawasan pengelolaan desa oleh BPD. Hasil penelitian menunjukkan 
munculnya perbedaan ekspektasi antara (1) anggota BPD dan kelompok masyarakat atas peran pengawasan yang sejatinya merupakan peran BPD dan atas peran pengawasan yang melebihi kapasitas BPD; (2) anggota BPD dan Camat atas peran pengawasan yang dimiliki oleh lembaga pengawasan non-BPD; dan (3) anggota BPD dan anggota Inspektorat Kabupaten atas peran pengawasan yang sejatinya merupakan peran BPD, peran pengawasan yang dimiliki oleh lembaga pengawasan non-BPD dan peran pengawasan yang melebihi kapasitas BPD. Selain itu, penelitian ini juga dilakukan dalam rangka menguji pengaruh pemahaman peran pengawasan terhadap kinerja pengawasan pengelolaan keuangan desa oleh BPD. Hasil penelitian mengindikasikan adanya hubungan yang bersifat positif antara pemahaman peran pengawasan yang dimiliki oleh BPD dan kinerja pengawasan pengelolaan keuangan desa yang dilakukannya.

Hasil penelitian dapat berimplikasi pada pemahaman teoretis atas fenomena expectation-gap fungsi pengawasan pengelolaan keuangan desa oleh Badan Permusyawaratan Desa. Kemunculan fenomena ini perlu disikapi dengan memberikan sosialisasi yang memadai kepada pihakpihak terkait mengenai peran pengawasan yang sesuai dengan tugas pokok dan fungsi berdasarkan peraturan perundang-undangan. Hal ini dengan mempertimbangkan bahwa meskipun pada indikator PPBPD mayoritas anggota BPD telah dengan tepat mengidentifikasikan peran pengawasan yang menjadi tanggung jawabnya, masih ditemukan banyak responden anggota BPD yang justru juga mengidentifikasikan beberapa peran pengawasan di luar kewenangannya sebagai tanggung jawab mereka. Dengan kata lain, secara empiris anggota BPD yang menjadi sampel pada penelitian ini sebenarnya telah gagal mengekspektasikan peran-peran mana saja yang memang menjadi kewenangan dan tanggung jawabnya.

\section{SARAN}

Penelitian ini tentunya tidak luput dari keterbatasan sehingga hasil-hasil yang diperoleh sepatutnya dapat dimaknai secara cermat dan bijaksana. Keterbatasan pertama bersumber dari penggunaan instrumen penelitian berupa kuesioner yang sarat akan bias-bias respon. Namun demikian, pengujian atas aspek validitas dan reliabilitas instrumen diyakini telah mampu meminimalisasi dampak negatif bias-bias tersebut. Penelitian selanjutnya dapat menerapkan metode campuran yang mengombinasikan teknik kuantitatif dan kualitatif sehingga hasil yang diperoleh dapat lebih komprehensif. Keterbatasan kedua terkait lingkup penelitian yang dilakukan pada 60 desa berbeda dengan karakteristik sosial masyarakat yang tentunya juga berbeda. Perbedaan ini bisa jadi turut berperan terhadap hasil penelitian yang diperoleh. Meskipun uji beda lokasi berdasarkan kecamatan menunjukkan tidak adanya perbedaan signifikan (nilai signifikansi Kruskal Wallis test $>0,05$ ), penelitian selanjutnya perlu mempertimbangkan pengujian jawaban responden berdasarkan perbedaan lokasi desa sebagai unit organisasi yang menjadi fokus pada penelitian dengan topik yang sejenis.

\section{DAFTAR PUSTAKA}

Agustina, L. 2009. Pengaruh Konflik Peran, Ketidakjelasan Peran, dan Kelebihan Peran terhadap Kepuasan Kerja dan Kinerja Audit (Penelitian pada Kantor Akuntan Publik yang Bermitra dengan Kantor Akuntan Publik Big Four di Wilayah DKI Jakarta). Jurnal Akuntansi, 1(1): 40-69.

Aini, N., M. A. Prayudi, dan P. G. Diatmika. 2018. Pengaruh Perspektif Fraud Diamond terhadap Kecenderungan Terjadi nya Kecurangan (Fraud) dalam Pengelolaan Keuangan Desa (Studi Empiris ada Desa di Kabupaten Lombok Timur). JIMAT (Jurnal Ilmiah Mahasiswa Akuntansi) Undiksha 8(2): 1-13. 
Antara Bali. 2010. Polres Buleleng Tangani Korupsi 10 Kepala Desa. [Online], Tersedia di: https://bali.antaranews. com/ berita/5465/polres-buleleng-tanganikorupsi-10-kepala-desa [Diakses pada 4 Desember 2017].

Artini, M. B., I. P. G. Diatmika, dan M. A. Prayudi. 2018. Pengaruh Akuntabilitas Publik, Kemampuan Kerja dan Pengawasan terhadap Kinerja Aparatur Pemerintah Desa (Studi Empiris pada Desa se-Kecamatan Seririt). JIMAT (Jurnal Ilmiah Mahasiswa Akuntansi) Undiksha 8(2).

Badan Pengawasan Keuangan dan Pembangunan (BPKP). 2015. Waspadai Titik Kritis, Wujudkan Good Village Governance. Warta Pengawasan XXII: 16-17.

Best, P. J., S. Buckby, dan C. Tan. 2001. Evidence of the Audit Expectation Gap in Singapore. Managerial Auditing Journal 16(3): 134-144.

Biddle, B. J. 1986. Recent Developments in Role Theory. Annual Reviews Sociology, 12:67-92.

Burney, L., dan S. K. Widener. 2007. Strategic Performance Measurement Systems, Job-Relevant Information, and Managerial Behavioural Responses Role Stress and Performance. Behavioral Research In Accounting 19(1): 43-69.

Chen, C.-K., dan J. Hughes. 2004. Using Ordinal Regression Model to Analyze Student Satisfaction Questionnaires. IR Applications: Advanced Tools, Techniques, and Methodologies 42: 1-13.

Deri, D. 2017. Peran Badan Permusyawaratan Desa (BPD) dalam Pengawasan Pengelolaan APBDes di Desa Senambah Kecamatan Muara Bengkal Kabupaten Kutai Timur In e-Journal Ilmu Pemerintahan 121-132.

Dewi, P. E. D. M., K. A. K. Saputra, dan M. A. Prayudi. 2017. Hubungan Kualitas Pengelolaan Aset Desa dan Pendapatan Asli Desa (Studi pada Desa-desa di Kabupaten Buleleng-Bali). Prosiding SEMINAR NASIONAL RISET INOVATIF 2017, di Bali, Indonesia.
Ebimobowei, A., dan O. J. Kereotu. 2011. Role Theory and the Concept of Audit Expectation Gap in South-South, Nigeria. Current Research Journal of Social Sciences 3(6):445-452.

Elamir, E., dan H. Sadeq. 2010. Ordinal Regression To Analyze Employees' Attitudes Towards The Application Of Total Quality Management. Journal of Applied Quantitative Methods 4(5): 647658.

Fauzan, A. 2010. Implementasi Peraturan Pemerintah Nomor 72 tahun 2005 tentang Desa terkait dengan Peran Badan Pemusyawaratan Desa dalam Penyusunan dan Penetapan Peraturan Desa di Kecamatan Wanasari Kabupaten Brebes. Tesis, Program Magister Hukum, Universitas Diponegoro, Semarang.

Fisher, R. T. 2001. Role Stress, the Type A Behaviour Pattern and External Auditor Job Satisfaction and Performance. Behavioral Research In Accounting 13(1): 143-170.

Indrayana, I. M., I. W. Parsa, dan I. N. Suharta. 2016. Pelaksanaan Fungsi Pengawasan Badan Permusyawaratan Desa (BPD) terhadap Kinerja Kepala Desa di Desa Antap Kecamatan Selemadeg Kabupaten Tabanan. Kertha Negara 4(2): 1-5.

Iyare, N. F. 2016. Ordinal Regression Model to Analyze Student Achievement Questionnaires in Barbados Public Secondary Schools. Imperial Journal of Interdisciplinary Research 2 (7): 1420-1430.

Kahn, R. L., D. M. Wolfe, R. P. Quinn, J. D. Snoek, dan R. A. Rosenthal. 1964. Organizational Stress. New York: Willey.

Linton, R. 1936. The Study of Man. New York: Appleton-Century.

Mangoto, K. 2016. Fungsi Badan Permusyawaratan Desa (BPD) dalam Pengawasan Penyelenggaraan Pemerintahan di Lesah Kecamatan Tagulandang Kabupaten Kepulauan Sitaro. Jurnal Politico 5(1): 1-11. 
Masoud, N. 2017. An Empirical Study of Audit Expectation-performance Gap: The Case of Libya. Research in International Business and Finance 4(12): 1-21.

Mead, G. H. 1934. Mind. Self and Society. Chicago: Univ. Chicago Press.

Moreno, C. L. 1934. Who Shall Survive? Washington, DC: Nervous and Mental Dis. Publ.

Nachar, N. 2008. The Mann-Whitney U: A Test for Assessing Whether Two Independent Samples Come from the Same Distribution. Tutorials in Quantitative Methods for Psychology 4(1): 13-20.

Pongsapan, R. 2012. The Audit Expectation Gap in Indonesian Public Sector. Jurnal Integrasi 4(1): 1-15.

Porter, B. 1993. An Empirical Study of the Audit Expectation-Performance Gap. Accounting and Business Research 24(93): 49-68.

Porter, B., C. Ó. hÓgartaigh, dan R. Baskerville. 2012. Audit Expectation-Performance Gap Revisited: Evidence from New Zealand and the United Kingdom, Part 1: The Gap in New Zealand and the United Kingdom in 2008. International Journal of Auditing 16(2): 101-129.

Prasetya, I. K. Y. B., M. A. Prayudi, dan I. P. G. Diatmika. 2018. Pengaruh Kompetensi Sumber Daya, Pemahaman, dan Pengawasan terhadap Kualitas Sistem Keuangan Desa di Kabupaten Buleleng. JIMAT (Jurnal Ilmiah Mahasiswa Akuntansi) Undiksha 8(2).

Putri, C. D., G. A. Yuniarta, dan M. A. Prayudi. 2017. Pengaruh Pengetahuan Peraturan, Kompetensi Sumber Daya Manusia, Monitoring dan Evaluasi terhadap Efektivitas Sistem Pengendalian Internal Pemerintah Desa (Studi pada Desa se-Kabupaten Karangasem). JIMAT (Jurnal Ilmiah Mahasiswa Akuntansi) Undiksha 8(2): 1-11.

Radar Buleleng. 2017. Diduga Korupsi, Perbekel Dencarik Ditahan. [Online], Tersedia di: https://www.jawapos.com/ radarbali/read/2017/11/07/25116/did uga-korupsi-perbekel-dencarik-ditahan [Diakses pada 4 Desember 2017].

Republik Indonesia. 2008. Peraturan Menteri Dalam Negeri Nomor 7 Tahun 2008 tentang Pedoman Tata Cara Pengawasan atas Penyelenggaraan Pemerintahan Desa. Jakarta.

- - - 2016. Peraturan Menteri Dalam Negeri Republik Indonesia Nomor 110 Tahun 2016 tentang Badan Permusyawaratan Desa. Jakarta.

Satriadi, N. 2013. Pengaruh Peran Badan Pemusyawaratan Desa dalam Pembentukan Peraturan Desa dengan Keluarnya Undang Undang Nomor 32 Tahun 2004 tentang Pemerintahan daerah. In E-Jurnal Ilmiah Universitas Mataram.

Simbolon, A. H., dan W. M. Sembiring. 2015. Evaluasi Kinerja Badan Permusyawaratan Desa dalam Penyelenggaraan Pemerintahan Desa. Jurnal Ilmu Pemerintahan dan Sosial Politik UMA 3(2): 143159.

Srikanth, P. B., dan M. G. Jomon. 2013. Role Ambiguity and Role Performance Effectiveness: Moderating the Effect of Feedback Seeking Behaviour. Asian Academy of Management Journal 18(2): 105-127.

Warsono, H., dan R. Ruksamin. 2014. The Obstacles of Implementation of Village Allocation Fund Program in the North Konawe Southeast Sulawesi. Journal of Management and Sustainability 4(3): 175183.

Williams, C. 2007. Research Methods. Journal of Business \& Economic Research 5(2): 65-72. 